\title{
Investigation of the effects on rheological and filtration properties of water- based drilling mud of boron minerals: An experimental study
}

\author{
Bor minerallerinin su bazlı sondaj çamurunun reolojik ve filtrasyon \\ özellikleri üzerindeki etkilerinin incelenmesi: Deneysel çalışma
}

\author{
Abdullah ÖZKAN ${ }^{*}$ iD , Behlül Merve KAPLAN² iD \\ 1,2Department of Petroleum \& Natural Gas Engineering, Iskenderun Technical University, Hatay, Turkey. \\ abdo.ozkan@gmail.com, behlulmervekaplan@gmail.com
}

Received/Geliș Tarihi: 14.11.2018, Accepted/Kabul Tarihi: 07.03.2019

doi: $10.5505 /$ pajes. 2019.89990

* Corresponding author/Yazıșllan Yazar Research Article/Araștırma Makalesi

\begin{abstract}
The aim of this study is to determine the effect on the rheological and filtration properties of water based drilling fluid of boron minerals. For this purpose, water-based drilling mud was prepared and borax (Na2B407.10H2O) with a particle size of $45 \mu \mathrm{m}$, ulexite (NaCaB509.8H2O) with a particle size of $75 \mu \mathrm{m}$ and colemanite (Ca2B6011.5H20) with a particle size of $100 \mu \mathrm{m}$ with different concentrations 1-5 (\% $\mathrm{w} / \mathrm{v})$ are separately added. The characterization of borax, uleksite and colemanite are examined using $X$-ray fluorescence spectrometer (XRF). The rheological properties such as apparent viscosity, plastic viscosity, yield point and gel strength of the developed mud systems adding boron minerals were determined with a FANN viscometer. The filtration properties were examined using an API Filter Press. All physical measurements were carried out according to the American Petroleum Institute (API) standards. Borax, ulexite and colemanite added $(1-5 \% \mathrm{w} / \mathrm{v})$ drilling muds rheological and filtration properties then compared to each other and the additive free water based drilling mud. The rheological and filtration properties of the developed mud systems are compared to original (additive free) mud system and with each other respectively. It is observed that boron additives improve the rheological properties of the drilling mud. Borax and colemanite have a better effect compared to ulexite. Filtration properties such as filtrate loss and filter cake thickness are increased compared to the original mud system but still in the reference value range and can be implemented to drilling operations.
\end{abstract}

Keywords: Boron minerals, Water based drilling fluid, Drilling mud, Rheological properties, Filtration loss

\section{Introduction}

Petroleum exploration activities are expanding as the energy demand increase. There are many reports about the drilling operations both in economically and technically. Drilling fluids account for approximately $10 \%$ of the drilling costs. Technological developments lead to highly efficient and cost effective drilling fluid explorations. In a drilling operation, drilling mud is one of the main components to remove rock fragments from the wellbore to implement necessary hydrostatic pressure to cool and lubricate whole systems and to ensure the stability of the hole [1]. Drilling mud is grouped mainly as water-based, oil-based and air-based, while waterbased mud is widely used in the industry [2]. Water-based drilling fluid includes in water, bentonite, viscosity increaser, fluid loss reducer etc. [3]. To improve drilling operations, a convenient drilling fluid is used. Many reports have shown that the related properties of drilling fluids are improved by some additives including polymers and nano-materials [4]-[6].
Öz

Bu çalıșmanın amacl, bor minerallerinin su bazlı sondaj çamurunun reolojik ve filtrasyon özellikleri üzerindeki etkisini incelemektir. Bu amaçla, su bazlı sondaj çamuru hazırlanarak içerisine $45 \mu \mathrm{m}$ partikül boyutuna sahip boraks (Na2B4O7.10H2O), 75 um partikül boyutuna sahip üleksit (NaCaB509.8H2O) ve 100 m partikül boyutuna sahip kolemanit (Ca2B6011.5H2O) farkl oranlarda (1-5\% w/v) eklenmiștir. Boraks, üleksit ve kolemanitin karekterizasyonu X-ıșinları floresans spektrometresi (XRF) ile yapılmıștır. Bor türevleri içeren su bazlı sondaj camurunun görünür viskozite, plastik viskozite, kopma noktası ve jel mukavemeti gibi reolojik özellikleri FANN viskozimetresi ile belirlenmiștir. Filtrasyon özellikleri, API Filter Presi kullanılarak incelenmiştir. Tüm ölçümler, Amerikan Petrol Enstitüsü (API) standartlarına göre gerçekleștirilmiștir. Boraks, üleksit ve kolemanit minerallerinin ayrı ayrı eklenmesi (\%1-5 w/v) ile hazırlanan sondaj çamurlarının reolojik ve filtrasyon özellikleri kendi içlerinde, daha sonra birbirleri ile ve son olarak ta katkısız su bazlı sondaj çamuru ile karşılaştırılmıştır. Bor minerallerinin sondaj çamurunun reolojik özelliklerine olumlu yönde katkı sağladığı tespit edilmiștir. Boraks ve kolemanitin, üleksite oranla daha iyi bir etkiye sahip olduğu görülmüștür. Katkısız su bazlı sondaj çamuruna klyasla, çamura bor mineralleri eklenmesinin çamurun filtrasyon kaybı ve kek kalınlığını attırdığı görülse de sonuçların referans değer aralığında olduğu tespit edilmiştir.

Anahtar kelimeler: Bor mineralleri, Su bazlı sondaj Sıvısı, Sondaj çamuru, Reolojik özellikler, Filtrasyon kaybı

Industrial minerals including nano and micro-sized particles have been used as a mud additive to improve rheological properties of the drilling fluid [7],[8]. Boron minerals such as colemanite and ulexite have been the subject of numerous patents in the energy industry in oil and gas exploration, drilling and well completion [9],[10]. For example, a water based drilling mud of colemanite $\left(\mathrm{Ca}_{2} \mathrm{~B}_{6} \mathrm{O}_{11} .5 \mathrm{H}_{2} \mathrm{O}\right)$ in the particle size of $100 \mu \mathrm{m}$ was reported. According to the results, the colemanite had a positive effect on the rheological properties [11]. In this study, The rheological properties of the developed mud systems such as plastic viscosity (PV), apparent viscosity $(\mathrm{AV})$, gel strength were investigated by FANN 35 viscometer while filtration properties like filtrate loss and cake thickness was analyzed using an American Petroleum Institute (API) fluid loss testing equipment [12]. 


\section{Experimental procedure}

\subsection{Sample preparation}

Water based fluids are the common drilling mud used in the oil industry. Water is the continuous phase, providing the initial rheological properties of the drilling fluid. First, in order to prepare the water based drilling fluid, bentonite and barite were provided from the Turkish Petroleum Corporation (TPAO). Mineral borax $\left(\mathrm{Na}_{2} \mathrm{~B}_{4} \mathrm{O}_{7} \cdot 10 \mathrm{H}_{2} \mathrm{O}\right)$ with the particle size of $45 \mu \mathrm{m}$, mineral ulexite $\left(\mathrm{NaCaB}_{5} \mathrm{O}_{9} .8 \mathrm{H}_{2} \mathrm{O}\right)$ with the particle size of $75 \mu \mathrm{m}$ and mineral colemanite $\left(\mathrm{Ca}_{2} \mathrm{~B}_{6} \mathrm{O}_{11} .5 \mathrm{H}_{2} \mathrm{O}\right)$ with the particle size of $100 \mu \mathrm{m}$ was obtained from Turkish Boron Institute. Water based drilling fluid (WBDF) system was then prepared by using fresh water, bentonite ( $5 \mathrm{wt} \%$ ) and barite as a densifier. The $\mathrm{pH}$ value of the fluid was adjusted by sodium hydroxide $(\mathrm{NaOH})$. After preparation of the mud, the system was mixed for 30 minutes in total. This drilling fluid was used as an arbitration specimen. Secondly, same drilling fluid was prepared by adding various amounts of borax, ulexite and colemanite $(1,2,3,4$ and 5 wt \%). The mixture was kept mixed for 3 minutes and then aged for 16 hours (average temperature $25^{\circ} \mathrm{C}$ ). Conventional WBDF and borax, ulexite and colemanite added WBDF formulations are given in (Table 1).

\subsection{Characterization of the Na-bentonite, Borax, Ulexite and Colemanite}

Chemical composition of the Na-bentonite was determined by X-ray fluorescence (XRF) and shown in (Table 2). As expected, the results showed that $\mathrm{SiO}_{2}$ and $\mathrm{Al}_{2} \mathrm{O}_{3}$ were the main components in the structures and Na-bentonite was suitable for the API Specification 13A standard [13],[14]. Chemical Compositions of borax, ulexite and colemanite are shown in (Table 3).

\subsection{Analysis of the physical properties}

The elemental compositions of the borax, ulexite and colemanite were determined by using an XRF instrument. The physical properties of the drilling mud were determined using a method based on API standard, including all filtration and rheological properties. The rheological properties such as apparent viscosity (AV), plastic viscosity (PV), yield point (YP) and gel strength of the boron minerals added to the drilling fluid were determined with a FANN viscometer. The filtration properties were also examined using an API Filter Press. All physical measurements were carried out according to the American Petroleum Institute (API) standards. FANN viscometer was used to investigate rheological properties. API (American Petroleum Institute) Filter press was utilized to measure the filtration properties of the different solutions. Rheological properties were correlated according to the empirical formulas given below;

$\begin{array}{ll}\mu \mathrm{p}=\theta(600 \mathrm{rpm})-\theta(300 \mathrm{rpm}) & \mu \mathrm{p}: \text { Plastic viscosity }(\mathrm{cp}) \\ \gamma \mathrm{p}=\theta(300 \mathrm{rpm})-\mu \mathrm{p} & \gamma \mathrm{p}: \text { Yield Point }(\mathrm{lbf} / 100 \mathrm{ft} 2) \\ \mu \mathrm{a}=(\theta(600 \mathrm{rpm})) / 2 & \mu \mathrm{a}: \text { Apparent viscosity }(\mathrm{cp})\end{array}$

The filtration properties of solutions were also determined by API (American Petroleum Institute) standard filter press equipment. 100 psi pressure was applied to the fluid column for 30 minutes and filtrate loss, as well as mud cake thickness, was recorded. Mud cake thickness was measured in 1/32". The density of the mud was also measured using mud balance method consisting of a base and a balance arm with a cup for counterweight.

\section{Results and discussions}

In this study, the effects of boron minerals addition such as borax $\left(\mathrm{Na}_{2} \mathrm{~B}_{4} \mathrm{O}_{7} .10 \mathrm{H}_{2} \mathrm{O}\right)$, sodium-calcium borate group ulexite $\left(\mathrm{NaCaB}_{5} \mathrm{O}_{9} .8 \mathrm{H}_{2} \mathrm{O}\right)$ and calcium borate group colemanite $\left(\mathrm{Ca}_{2} \mathrm{~B}_{6} \mathrm{O}_{11} .5 \mathrm{H}_{2} \mathrm{O}\right)$ respectively, to the rheological and filtration properties of water based drilling mud were examined. In addition, the results obtained were compared with the rheological and filtration properties of water-based drilling mud consisting of only bentonite, barite and water (additive free). All data in this study was given on Table 4. According to Table 4, the positive effect on rheological properties such as apparent viscosity, plastic viscosity, yield point and gel strength of the developed mud systems was obtained in comparison with API standards.

Table 1: Formulations of the developed mud systems.

\begin{tabular}{|c|c|c|c|c|c|c|}
\hline \multirow{2}{*}{ Materials } & \multirow{2}{*}{ WBDF } & \multicolumn{5}{|c|}{ Borax, Ulexite and Colemanite added WBDF (w/v \%) } \\
\hline & & $1 \%$ & $2 \%$ & $3 \%$ & $4 \%$ & $5 \%$ \\
\hline Bentonite (g) & 22.8 & 22.8 & 22.8 & 22.8 & 22.8 & 22.8 \\
\hline Fresh water (g) & 400 & 400 & 400 & 400 & 400 & 400 \\
\hline $\begin{array}{l}\mathrm{NaOH}(\mathrm{g}) \\
\text { Borax }(\mathrm{g})\end{array}$ & 1 & 1 & 1 & 1 & 1 & 1 \\
\hline $\begin{array}{c}\text { Ulexite }(\mathrm{g}) \\
\text { Colemanite }(\mathrm{g})\end{array}$ & - & 4.35 & 8.70 & 13.05 & 17.4 & 21.75 \\
\hline
\end{tabular}

Table 2: Chemical composition of the Na-bentonite.

\begin{tabular}{ccccccccc}
\hline \multirow{2}{*}{ Sample } & \multicolumn{9}{c}{ Content of Oxides (wt \%) } \\
\cline { 2 - 8 } & $\mathrm{Na}_{2} \mathrm{O}$ & $\mathrm{MgO}$ & $\mathrm{Al}_{2} \mathrm{O}_{3}$ & $\mathrm{SiO}_{2}$ & $\mathrm{~K}_{2} \mathrm{O}$ & $\mathrm{CaO}_{2}$ & $\mathrm{TiO}_{2}$ & $\mathrm{Fe}_{2} \mathrm{O}_{3}$ \\
\hline Na-Bentonite & 2.48 & 2.44 & 20.9 & 65.85 & 0.75 & 1.44 & 0.29 & 5.85 \\
\hline
\end{tabular}

Table 3: Chemical compositions of borax, ulexite and colemanite.

\begin{tabular}{ccccc}
\hline \multirow{2}{*}{ Material } & \multicolumn{5}{c}{ Content of Oxides $(w t$ \%) } \\
\cline { 2 - 5 } & $\mathrm{B}_{2} \mathrm{O}_{3}$ & $\mathrm{CaO}$ & $\mathrm{Na}_{2} \mathrm{O}$ & $\mathrm{H}_{2} \mathrm{O}$ \\
\hline Borax & 36.51 & - & 16.25 & 47.24 \\
Ulexite & 42.95 & 13.84 & 7.65 & 35.57 \\
Colemanite & 50.90 & 27.20 & - & 21.90 \\
\hline
\end{tabular}


Table 4: Rheological and Filtration results of the drilling mud.

\begin{tabular}{|c|c|c|c|c|c|c|c|c|c|c|c|c|c|c|c|c|c|}
\hline \multirow{3}{*}{ Parameters } & \multirow{3}{*}{$\begin{array}{c}\text { API } \\
\text { Standarts }\end{array}$} & \multirow{3}{*}{$\begin{array}{l}\text { WBDF } \\
\text { (free } \\
\text { additive) }\end{array}$} & \multicolumn{15}{|c|}{ Boron inerals added WBDF (w/v \%) } \\
\hline & & & \multicolumn{3}{|c|}{$\% 1$} & \multicolumn{3}{|c|}{$\% 2$} & \multicolumn{3}{|c|}{$\% 3$} & \multicolumn{3}{|c|}{$\% 4$} & \multicolumn{3}{|c|}{$\% 5$} \\
\hline & & & $\begin{array}{c}45 \\
\mu \mathrm{m} \\
\end{array}$ & $\begin{array}{r}75 \\
\mu \mathrm{m} \\
\end{array}$ & $\begin{array}{l}100 \\
\mu \mathrm{m}\end{array}$ & $45 \mu \mathrm{m}$ & $\begin{array}{r}75 \\
\mu \mathrm{m} \\
\end{array}$ & $\begin{array}{l}100 \\
\mu \mathrm{m}\end{array}$ & $\begin{array}{c}45 \\
\mu \mathrm{m}\end{array}$ & $\begin{array}{l}75 \\
\mu \mathrm{m}\end{array}$ & $\begin{array}{l}100 \\
\mu \mathrm{m}\end{array}$ & $\begin{array}{c}45 \\
\mu \mathrm{m}\end{array}$ & $\begin{array}{r}75 \\
\mu \mathrm{m}\end{array}$ & $\begin{array}{l}100 \\
\mu \mathrm{m}\end{array}$ & $\begin{array}{l}45 \\
\mu \mathrm{m}\end{array}$ & $\begin{array}{l}75 \\
\mu \mathrm{m}\end{array}$ & $\begin{array}{l}100 \\
\mu \mathrm{m}\end{array}$ \\
\hline $\mathrm{PV}(\mathrm{cP})$ & $\operatorname{Min} 7$ & 11.5 & 12 & 9 & 13.3 & 12.5 & 9 & 14 & 13 & 9 & 14.1 & 13.5 & 10 & 14.8 & 17 & 10 & 15 \\
\hline $\mathrm{YP}(\mathrm{lb} / 100 \mathrm{ft} 2)$ & Max 50 & 9 & 31 & 24 & 15 & 32 & 28 & 18 & 32 & 35 & 21 & 38 & 35 & 24 & 39 & 37 & 20 \\
\hline $\mathrm{AV}(\mathrm{cP})$ & Min 15 & 16 & 18.5 & 21 & 22.5 & 19.25 & 23 & 24 & 21.5 & 26.5 & 25.5 & 22 & 27.5 & 27 & 28.5 & 28.5 & 25 \\
\hline $\begin{array}{c}\text { Gel at } \\
10 \text {-second }\end{array}$ & 15 & 11 & 10 & 24 & 10 & 11 & 25 & 13 & 14 & 29 & 15 & 16 & 34 & 15 & 23 & 35 & 20 \\
\hline $\begin{array}{c}\text { Gel at } \\
10 \text {-minute }\end{array}$ & 31 & 35 & 23 & 31 & 33 & 24 & 32 & 33 & 25 & 34 & 34 & 30 & 35 & 35 & 33 & 42 & 39 \\
\hline $\begin{array}{l}\text { Liquid loss } \\
\text { (mL) }\end{array}$ & $10-15$ & 9.6 & 15.2 & 18 & 10 & 12.8 & 18 & 10.8 & 11.2 & 19.6 & 11.2 & 11.6 & 19.6 & 11.6 & 12.8 & 19.6 & 12.8 \\
\hline Cake thickness (mm) & 4 & 0.20 & 0.21 & 0.23 & 0.25 & 0.25 & 0.25 & 0.32 & 0.28 & 0.31 & 0.42 & 0.30 & 0.35 & 0.48 & 0.33 & 0.40 & 0.50 \\
\hline
\end{tabular}

3.1 Effect of the borax, ulexite and colemanite ratio on rheological and filtration properties of water based drilling fluids

Viscosity is generally defined as resistance to flow interacts directly with temperature, solids content, additives and preservatives incorporated into the mud and the pump force. Viscosity is measured in terms of apparent viscosity (AP), plastic viscosity (PV) and yield point (YP). AV is the viscosity of the fluid under a certain force or at a certain rate of flow. PV is a constant value that characterizes the flow region. YP is the initiating force. Viscosity values of the different boron additives and compositions are shown in the (Figure 1, Figure 2 and Figure 3).

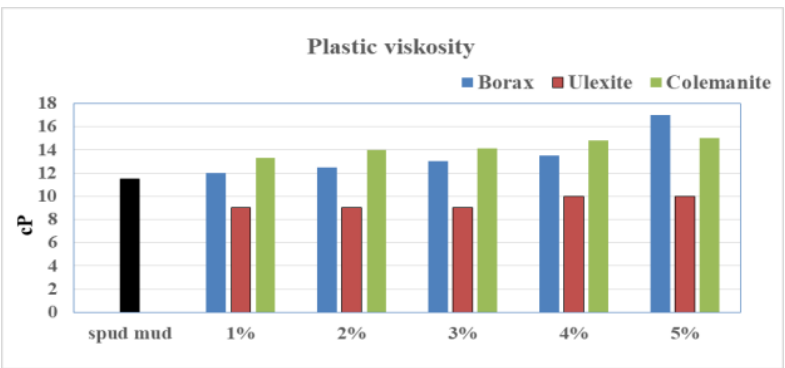

Figure 1: Plastic viscosities of the developed mud systems.

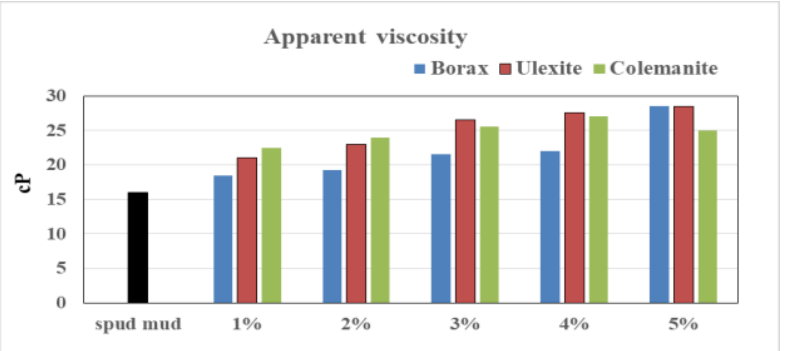

Figure 2: Apparent viscosities of the developed mud systems.

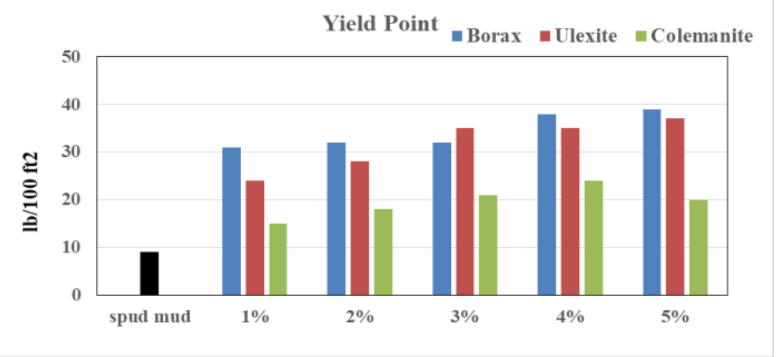

Figure 3: Yield points of the developed mud systems.
Plastic viscosities of the mud increases as borax and colemanite concentrations in the mud increases, however, it is observed that plastic viscosity decreases with ulexite addition, after $3 \%$ ulexite concentration, plastic viscosity gets uptrend but still below the spud mud value. For the apparent viscosities, all three additives increase the apparent viscosity of the original mud with borax to be the most effective for the rise among the others. It is seen that the addition of boron minerals into the drilling fluid could provide better flowability and reduce the possible problems such as surge, swab pressure, differential sticking and slow rate of penetration [15],[16]. It is also noted that ulexite addition negatively affects plastic viscosity.

The yield point is also important for the selection of pump and pressure needed to flow the mud from static positions [17]. All these boron minerals additions increase yield point of the mud; borax and ulexite increases the yield point 3 times than the original mud while the yield point tends to decrease after $4 \%$ colemanite addition.

In addition, as shown in the (Figure 4 and Figure 5) the developed mud systems had a high gel strength, which is desirable for eliminating problems in drilling operations such as poor hole cleaning, high torque and drag, pipe sticking, wellbore instability, lost circulation and formation damage [18].

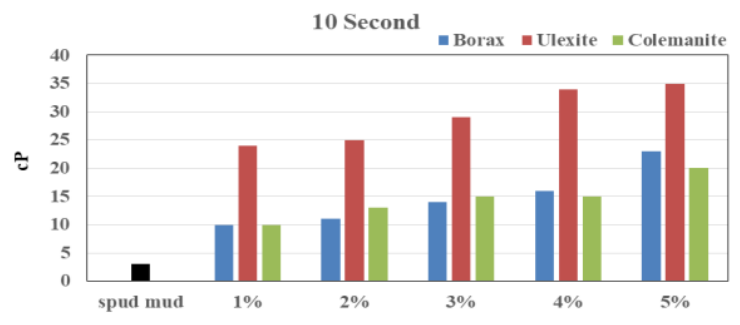

Figure 4: Gel strength (10 second) of the developed mud systems.

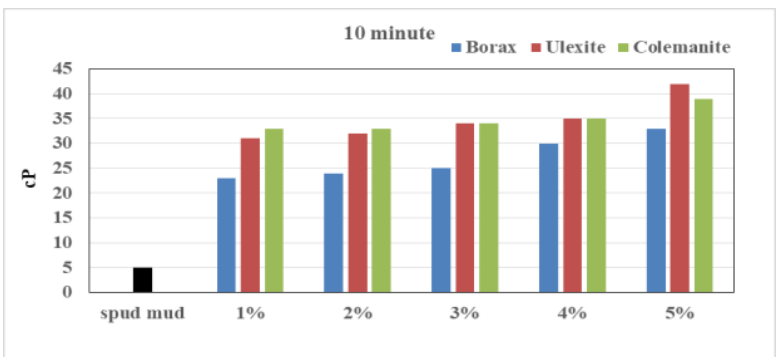

Figure 5: Gel strength (10 minute) of the developed mud systems. 
For the 10 seconds gel strength, ulexite addition to mud shows an considerable effect, the value was 6 times higher than the original mud. Borax and colemanite additions also increase the gel strength of the developed mud systems but the effect is lower compared to the ulexite addition.

Both 10 seconds and 10 minutes gels strength values of the systems increase with the increasing concentrations. For ulexite and colemanite additions, the 10 minute gel strength is increases with $1 \%$ concentration, after that concentration the change is almost negligible from $1 \%$ to $4 \%$, after $5 \%$ concentration the change in 10 seconds gel strength is visible as well.

It is desirable that the fluid loss rate of the drilling mud should be in the range of $10-15 \mathrm{~mL}$, as the loss of fluid to be sustained by the continuously circulating mud in the borehole may cause the drilling equipment to get stuck in the well, lock the pipe and possibly overload. Filter cake thickness is also important to prevent significant borehole problems such as equipment stucking, wellbore stability and ensure that productive zones are not contaminated as well as the proper well log evaluation [19]. In this regard, the data obtained from the study are given in the (Figure 6 and Figure 7).

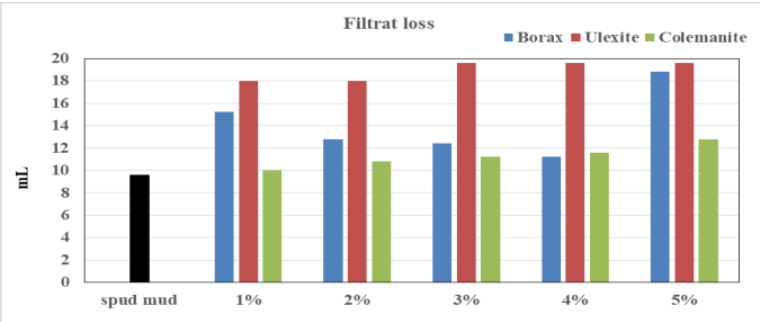

Figure 6: Filtration loss of the developed mud systems.

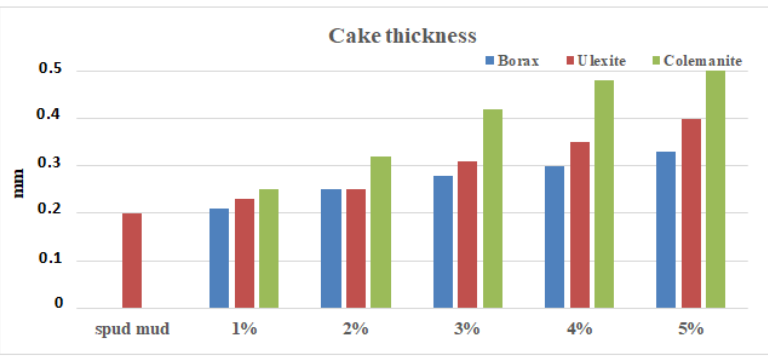

Figure 7: Filter cake thickness of the developed mud systems.

Filtrate losses of the developed systems are higher that of the original mud systems and they even keep increasing as the concentration increases. Ulexite addition gives the most negative effect on filtration loss of the system with increasing the filtration loss by $83 \%$ at an addition rate of $1 \%$. Colemanite addition shows the least effect on filtration properties. Filtration characteristic of the borax is different than those of ulexite and colemanite. In the first place, borax addition of $1 \%$ to mud system increases filtration losses up to $15.2 \mathrm{ml}$ from the original value of $9.8 \mathrm{ml}$. As the concentration is $2 \%, 3 \%$ and $4 \%$, filtration losses become $12.8 \mathrm{ml}, 12.4 \mathrm{ml}$ and $11.2 \mathrm{ml}$, respectively.

The surfaces of the drilling mud and the filter cake are desired to be smooth and the cake thickness to be $1-2 \mathrm{~mm}(\max 4 \mathrm{~mm})$. Obtained cake thickness of the developed systems is given below.
Filter cake thickness of the developed mud systems are increases with concentration. Besides, filter cake thickness of the mud systems increases as particle size increases. Since borax has the minimum particle size with the $45 \mu \mathrm{m}$, filter cake thickness of borax is lower than those of the others while $100 \mu \mathrm{m}$ particles sized colemanite added mud system has the highest cake thickness.

Filtration properties of the mud systems are expected to improve as the particle size decreases, therefore, addition of nano sizes of these materials should further investigated.

\section{Conclusions}

In this study, the effect of borax, ulexite and colemanite additions on the rheological and filtration properties of drilling mud was investigated. These aforementioned boron minerals were added into drilling mud at various concentrations as 1-5\% $(\mathrm{w} / \mathrm{v})$. Particle sizes of the additives were also different and borax, ulexite, and colemanite with particle sizes $45 \mu \mathrm{m}, 75 \mu \mathrm{m}$ and $100 \mu \mathrm{m}$ of were added, respectively. Results have shown that rheological properties such as plastic viscosity (PV) and apparent viscosity (AP) of the drilling mud were improved with borax and colemanite additions while ulexite addition negatively affected plastic viscosity. Yield points of all three developed mud systems prepared with boron minerals were increased. Both 10 seconds and 10 minutes gels strengths of the systems increasing with increased with increasing concentrations. Filtrate losses and the filter cake thickness, which are not desirable for a proper drilling operation, of the developed systems were found higher than those of the original mud systems and increased with the concentration increase. However, the filtrate loss and filter cake thickness of the developed systems are still in the reference value range. Filtration properties of the mud systems are supposed to be improved as the particle size decreases; therefore, the addition of nano sized boron minerals should be further investigated.

\section{References}

[1] Abdo J, Haneef M. "Nano-enhanced drilling fluids: pioneering approach to overcome uncompromising drilling problems". Journal of Energy Resources Technology, 134(1), 014501 (1-6), 2012.

[2] Benchabone A, Bekkour K. "Effect of anionic additives on the rheological behaviour of aqueous calcium montmorillonite suspensions". Rheologica Acta, 45(4), 425-434, 2006.

[3] Amanullah M, Arfaj MK, Abdullati ZA. "Effect of $\mathrm{CuO}$ and $\mathrm{ZnO}$ nanofluids in xanthan gum on thermal, electrical and high pressure rheology of water-based drilling fluids". Journal of Petroleum Science and Engineering, 117, 1-9, 2011.

[4] Zhong QZ, Huang W, Cao J. "Shale inhibitive properties of polyether diamine in water-based drilling fluid, Hanyi". Journal of Petroleum Science and Engineering, 78(2), 510-515, 2011.

[5] Amanullah M., Yu L. "Environment friendly fluid loss additives to protect the marine environment from the detrimental effect of mud additives". Journal of Petroleum Science and Engineering, 48, 199-208, 2005.

[6] Gentzis T, Deisman N, Chalaturnyk RJ. "Effect of drilling fluids on coal permeability: Impact on horizontal wellbore stability". International Journal of Coal Geology, 78, 177-191, 2009. 
[7] Wenga J, Gonga Z, Liaoa L, Lva G, Tanb J. “Comparison of organo-sepiolite modified by different surfactants and their rheological behavior in oil-based drilling fluids". Applied Clay Science, 159, 94-101, 2018.

[8] Zhuanga G, Zhanga Z, Yang H, Tan J. "Structures and rheological properties of organo-sepiolite in oil-based drilling fluids". Applied Clay Science, 154, 43-51, 2018.

[9] Eti Mine. Kestelek colemanite. Product atalogue, p.2. Ankara, Eti Mine Works General Management Publishing, 2014a.

[10] Eti Mine. Milled colemanite. Product catalogue, p.3. Ankara, Eti Mine Works General Management Publishing, 2014b.

[11] Özkan A, Kaplan BM, Özkan V, Turan SE. "Effect of micro-sized colemanite on the rheological properties of the water based drilling fluid". Çukurova University Journal of the Faculty of Engineering and Architecture, 33(4), 83-88, 2018.

[12] API R. "13-B1: Recommended practice for field testing of water-based drilling fluids". American Petroleum Institute. ANSI/API 13B-1/ISO 10414-1, 2003.

[13] Shah SN, Shanker NH, Ogugbue CC. "Future challenges of drilling fluids and their rheological measurements". In American Association of Drilling Engineers, Fluids Conference and exhibition, Houston, Texas, 6-7 April 2010.
[14] API R. "13-A: Specification for drilling fluid materials". American Petroleum Intitute, ANSI/API 13A/ISO 13500, 2010.

[15] Falode OA, Ehinola OA, Nebeife PC. "Evaluation of local bentonite clay as oil well drilling fluid in Nigeria". Applied Clay Science, 39(1-2), 19-27, 2008.

[16] Xianhai M, Yihe Z, Paul KC. "Effects of carbon ash on rheological properties of water-based drilling fluids". Journal of Petroleum Science and Engineering, 100, 1-8, 2012.

[17] Ahmaruzzaman M. "A review on the utilization of fly ash". Progress in Energy and Combustion Science, 36(3), 327-363, 2010.

[18] Kasiralvalad E. "The great potential of nanomaterials in drilling \& drilling fluid applications". International Journal of Nano Dimension, 5(5), 463-471, 2014.

[19] Ersoy A. Sondaj Teknikleri ve Uygulamaları. Adana, Türkiye, Nobel Kitabevi, 2008. 